\title{
Effect of organic load of refinery wastewater in municipal wastewater treatment using bench scale extended aeration activated sludge system
}

\author{
M. A. R. M. M. Amin, S. R. M. Kutty \& M. H. Isa \\ Civil Engineering Department, \\ Universiti Teknologi PETRONAS, Malaysia
}

\begin{abstract}
Petroleum refinery wastewater has the characteristic of a high concentration of aliphatic and aromatic petroleum hydrocarbons, which could lead to heavy pollution to the environment. In this study, petroleum refinery wastewater was co-treated with municipal wastewater in continuous flow bench scale reactors. Two bench scale reactors, $\mathrm{A}$ and $\mathrm{B}$ each of liquid volume of $18 \mathrm{~L}$ treats municipal wastewater and a mixture of municipal and refinery wastewater, respectively. The flow rate, $\mathrm{Q}$ for both reactors was maintained at $9 \mathrm{~L} /$ day with the hydraulic retention time (HRT) and sludge retention time (SRT), set at 2 days and 40 days, respectively. Food to microorganism $(\mathrm{F} / \mathrm{M})$ ratio, concentration of effluent soluble chemical oxygen demand (sCOD), mixed liquor suspended solids (MLSS), and mixed liquor volatile suspended solids (MLVSS) were monitored throughout the study period. The result of a full five months operation show high removal efficiencies of organic matter of about $90 \%$ as sCOD with $30 \%$ loading of the refinery wastewater.

Keywords: continuous flow, organic loading, refinery wastewater, extended aeration, biological treatment, activated sludge.
\end{abstract}

\section{Introduction}

Petroleum refining involves the transformation of crude oil into final useful products such as gasoline, gas oil, kerosene and jet fuel, and petrochemical feed stocks. Petroleum refining uses relatively large quantities of water, especially for cooling systems, desalting water, stripping steam, and water used for flushing during maintenance and shut down. As a general rule, approximately $3.5-5 \mathrm{~m}^{3}$ of 
wastewater is generated per tonne of crude oil processed when cooling water is recycled [1]. Wastewater discharge from oil refineries mostly contains organics, oil, phenols, solvents, and toxic substances [2]. It is therefore, necessary to remove such organics and toxic substances from refinery wastewaters in order to reduce and remove their harm to the environment.

Among various methods developed for refinery wastewater treatment, biological degradation is the most economical and efficient means for eliminating pollutants [3]. Out of many different processes employed, the activated sludge system has proven to be the most popular [4]. It is because the activated sludge system or suspended growth system, where microorganisms in activated sludge were constantly dispersed throughout the wastewater by mechanical and/or air agitation, can incorporate a number of different processes of aeration technologies in its design. Furthermore, activated sludge in the presence of oxygen is considered to be a relatively simple, inexpensive and environmentally sound way to degrade wastes [5]. In addition, activated sludge systems can be operated at high sludge recycle ratios to achieve both high biomass concentrations within the reactor, and minimize biological solids formation [6]. It has been shown to be successful in many processes and in the treatment of a variety of wastes including refineries [7]. During the degradation process organic materials are converted into carbon dioxide, water and mineral organic matter [8].

The sludge retention time (SRT) is the time where the activated sludge remains in the reactor before wasted. Long SRT (28 d) resulted in high chemical oxygen demand (COD) removal, which showed an improved removal of biochemical oxygen demand (BOD), and COD [9]. More studies [10-12] have concluded that extending the SRT improved the removal efficiency for biological degradation. The studies showed that extended aeration (continuous flow) has the highest percent removal efficiency for biological degradation $(>90 \%)$. Another study [13] found that during the pilot experiment, the SRT varied from 1200 to $2400 \mathrm{~h}$ and the average removal rate of COD remained at $98 \%$. It proved that the removal rate of organic pollutants was high and stable when SRT $=2400 \mathrm{~h}$. In this study, the extended aeration $($ SRTs $=40 \mathrm{~d}$ ), continuous flow bench scale activated sludge bioreactors were investigated on the impact of organic load of refinery wastewater in municipal wastewater treatment.

\section{Methodology}

\subsection{Objectives of study}

The objectives of this study are to determine the impact of increased organic load of refinery wastewater on municipal wastewater treatment operated at long sludge age of 40 days. The impact of increased organic load of the refinery wastewater was evaluated by increasing the concentration of refinery wastewater at $10 \%, 20 \%$ and $30 \%$ in the influent feed. The COD in the influent and effluent tanks was continuously monitored throughout the study period. 


\subsection{Experimental set-up and procedure}

Two continuous flow bench scale reactors were constructed using $1 \mathrm{~cm}$ thick Perspex. The height and the width, of the reactors were $20 \mathrm{~cm}$ and $30 \mathrm{~cm}$, respectively. The lengths of the aeration chamber and the settling chamber, were $31 \mathrm{~cm}$ and $16 \mathrm{~cm}$, respectively. Total liquid volume in the tank was $18 \mathrm{~L}$. The experimental set-up consisted of a raw refinery wastewater influent tank, a stirrer with stand, an influent line, a peristaltic pump, an aeration chamber, air supply, air diffuser stones connected to air supply, a settling chamber, an overflow line for effluent and effluent tank as shown in fig. 1.

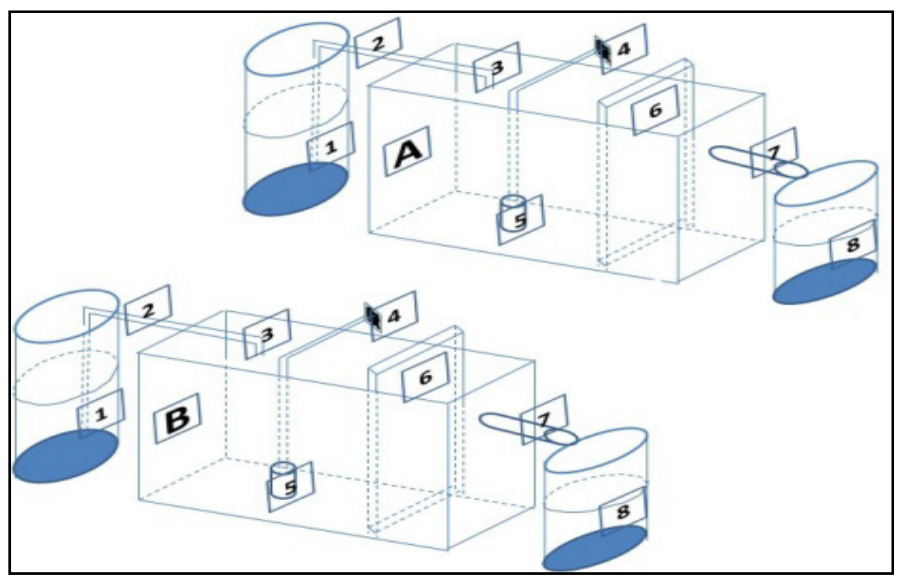

Figure 1: A three-dimensional diagram of continuous flow bench scale reactor. 1. Refinery wastewater influent tank, 2. Peristaltic pump, 3. Influent line, 4. Air supply, 5. Air diffuser stone, 6. Sliding baffle, 7. Overflow line, 8.Effluent tank.

Raw refinery wastewater was obtained from an oil refinery industry and stored at $4^{\circ} \mathrm{C}$ prior to treatment. Wastewater in the influent tank was continuously stirred to keep solids in suspension. The wastewater was fed into two parallel reactors $\mathrm{A}$ and $\mathrm{B}$. Reactor $\mathrm{A}$ acts as a control and treats only municipal wastewater while reactor B treats a mixture of municipal wastewater and refinery wastewater. The percentage of refinery wastewater in the influent to reactor B was added in stages at $10 \%, 20 \%$ and $30 \%$. Initially, both reactors were acclimatized with municipal wastewater for 13 days prior to feeding of the refinery wastewater to reactor B. Both reactors were seeded with $1.1 \mathrm{~L}$ biomass taken from a municipal sewage treatment plant (STP). Aeration to the reactors was supplied through stone diffusers at $2.5-4.0 \mathrm{mg} / \mathrm{L}$ of oxygen. The study was conducted at room temperature and $\mathrm{pH}$, at approximately $26{ }^{\circ} \mathrm{C}$ and 7.0 , respectively. The flow rate, $\mathrm{Q}$ for both reactors was maintained at $9 \mathrm{~L} / \mathrm{d}$ with the hydraulic retention time (HRT) and SRT, set at 2 days and 40 days, respectively. 
The sludge age was maintained for 40 days by daily wasting $0.45 \mathrm{~L}$ of biomass from the clarifier. Sampling of the feed and effluent wastewater were collected and analyzed in triplicates for the various parameters such as SCOD, MLSS, and MLVSS.

\subsection{Wastewater characteristics}

Table 2 and table 3, show the characteristics of the refinery wastewater and municipal wastewater used in this study, respectively.

Table 1: $\quad$ Refinery wastewater characteristic.

\begin{tabular}{|l|c|}
\hline $\begin{array}{c}\text { Wastewater } \\
\text { Parameter }\end{array}$ & $\begin{array}{c}\text { Concentration } \\
\text { (Effluent) }\end{array}$ \\
\hline COD & $1200 \mathrm{mg} / \mathrm{L}$ \\
\hline Ammonia & $9.3 \mathrm{mg} / \mathrm{L}$ \\
\hline Nitrate & $9.3 \mathrm{mg} / \mathrm{L}$ \\
\hline Phosphorus & $3.7 \mathrm{mg} / \mathrm{L}$ \\
\hline $\mathrm{pH}$ & 6.7 \\
\hline
\end{tabular}

Table 2: Municipal wastewater characteristic.

\begin{tabular}{|l|c|c|}
\hline \multirow{2}{*}{$\begin{array}{c}\text { Wastewater } \\
\text { Parameter }\end{array}$} & \multicolumn{2}{|c|}{ Concentration } \\
\cline { 2 - 3 } COD & $34.6 \mathrm{mg} / \mathrm{L}$ & $19.0 \mathrm{mg} / \mathrm{L}$ \\
\hline Ammonia & $2.95 \mathrm{mg} / \mathrm{L}$ & $0.19 \mathrm{mg} / \mathrm{L}$ \\
\hline Nitrate & $0.13 \mathrm{mg} / \mathrm{L}$ & $2.43 \mathrm{mg} / \mathrm{L}$ \\
\hline Phosphorus & $1.31 \mathrm{mg} / \mathrm{L}$ & $0.65 \mathrm{mg} / \mathrm{L}$ \\
\hline $\mathrm{pH}$ & 7.1 & 7.0 \\
\hline
\end{tabular}

\subsection{Analytical method}

Samples were collected from the influent and effluent tanks every 2 days and filtered prior to measurement of sCOD. The COD was determined using the dichromate reflux method according to the Standard Methods [14]. $2 \mathrm{~mL}$ of samples was placed into a COD vial and digested at $150{ }^{\circ} \mathrm{C}$ for two hours in a COD block digester (Hach DRB200). The samples were analyzed in triplicates. The COD was measured using DR2800 spectrophotometer. Biomass concentrations, MLSS in the reactors were determined by first diluting at 1:10 ratio prior to filtration through a $4.5 \mu \mathrm{m}$ fiber filter paper. It was then dried in an oven at $105^{\circ} \mathrm{C}$ for at least 1 hour [15]. It was then further dried in a furnace at a temperature of $550^{\circ} \mathrm{C}$ for 20 minutes for MLVSS determination. Samples for MLSS and MLVSS were also analyzed in triplicates. 


\section{Results and discussion}

\subsection{Organic COD loading}

Fig. 2 shows the organic COD loading vs sampling days throughout the study period. The organic COD loading of both reactors was observed to be unsteady during the acclimatization phase. The municipal wastewater source was taken from the influent to an STP and was sometimes unstable. However, the organic COD loading to the reactor A stabilized after 33 sampling days until the end of the study period at approximately $6.3 \times 10^{-8} \mathrm{~kg} \mathrm{COD} / \mathrm{m}^{3} . \mathrm{d}$. When the loading in reactor $\mathrm{B}$ was increased with addition of $10 \%$ of the refinery wastewater, the organic COD load can be observed increased to approximately $1.3 \times 10^{-7} \mathrm{~kg}$ $\mathrm{COD} / \mathrm{m}^{3} . \mathrm{d}$ at the end of the loading period. When the refinery wastewater was increased to $20 \%$ in reactor $\mathrm{B}$, the organic COD loading increased to approximately $1.4 \times 10^{-7} \mathrm{~kg} \mathrm{COD} / \mathrm{m}^{3} . \mathrm{d}$, however, at 67 sampling days the organic COD loading dropped to $1.2 \times 10^{-7} \mathrm{~kg} \mathrm{COD} / \mathrm{m}^{3} . \mathrm{d}$ due to slight degradation of the stock samples of the refinery wastewater. When the refinery wastewater was increased to $30 \%$, the organic COD load increased to approximately $2.0 \times 10^{-7} \mathrm{~kg}$ $\mathrm{COD} / \mathrm{m}^{3} . \mathrm{d}$. When fresh refinery samples was collected and fed at $30 \%$, the loading was increased to $3.5 \times 10^{-7} \mathrm{~kg} \mathrm{COD} / \mathrm{m}^{3} . \mathrm{d}$ and stabilized to approximately $2.9 \times 10^{-7} \mathrm{~kg} \mathrm{COD} / \mathrm{m}^{3} . \mathrm{d}$ until the end of the period.

Organic COD loading $\left(\mathbf{k g} / \mathrm{m}^{3} \cdot \mathrm{d}\right)$ vs Sampling days

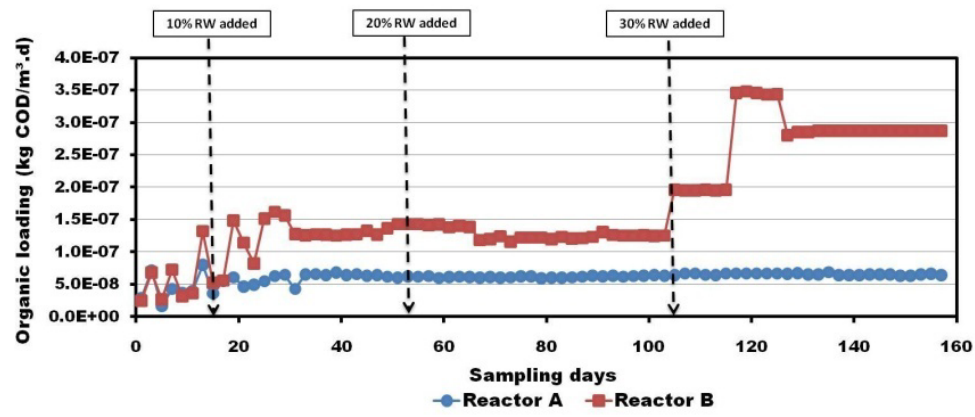

Figure 2: $\quad$ Organic COD loading vs. sampling days.

\section{$3.2 \mathrm{sCOD}$ removal}

Fig. 3 and fig. 4, show sCOD removal vs sampling days for reactors A and B, respectively. From fig. 3, it can be observed that throughout the study period, the percent sCOD removal remain constant at $80 \%$ with effluent COD averaged at $23 \mathrm{mg} / \mathrm{L}$. This meets the standard limits for discharge [16]. In Fig. 4, prior to addition of $10 \%$ refinery wastewater, the averaged effluent COD was $23 \mathrm{mg} / \mathrm{L}$ with sCOD removal of approximately $80 \%$. When the organic load was increased with $10 \%$ refinery wastewater, it can be observed that effluent sCOD of reactor B was immediately impacted resulting in increased effluent SCOD to 
Effluent SCOD \& percent COD removal vs Sampling days

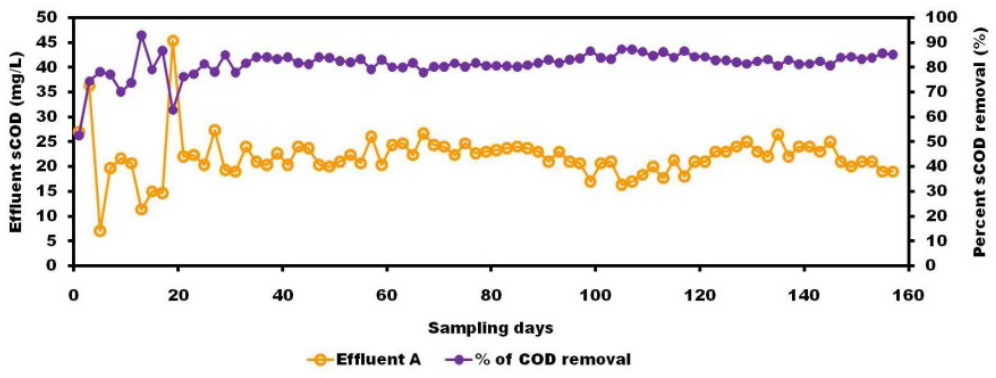

Figure 3: Percent SCOD removal vs. sampling days of reactor A.

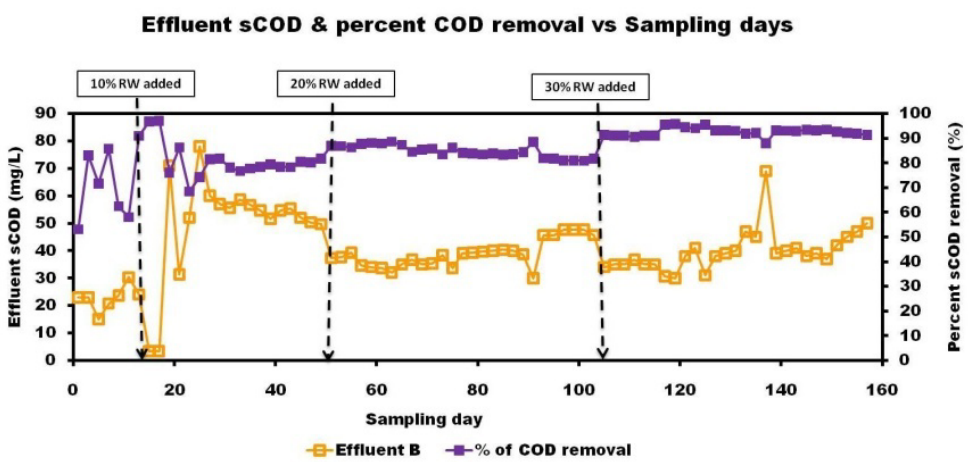

Figure 4: $\quad$ Percent SCOD removal vs. sampling days of reactor B.

$86 \mathrm{mg} / \mathrm{L}$. However, the reactor acclimatized and stabilized to effluent sCOD and sCOD removal, with averaged at $51 \mathrm{mg} / \mathrm{L}$ and $78 \%$, at the end of the period, respectively. When the refinery wastewater was increased to $20 \%$, a slight increase in effluent SCOD was observed throughout this addition period with the final effluent sCOD and effluent sCOD removal, at $47 \mathrm{mg} / \mathrm{L}$ and of $81 \%$, respectively. Effluent sCOD averaged at $35 \mathrm{mg} / \mathrm{L}$ throughout this period which still meet the limit for effluent discharge. When the refinery wastewater loading was increased to $30 \%$, not much impact was observed on effluent sCOD with effluent sCOD averaged at $39 \mathrm{mg} / \mathrm{L}$ throughout this loading period. It was also observed that as the reactor acclimatized, the average percentage removal of sCOD increased from $90 \%$ to $94 \%$ at 117 days. Hence, it can be observed that the discharge limits was still met at $30 \%$ loading of the refinery wastewater.

\subsection{MLSS and MLVSS}

Fig. 5 shows the consistency of the MLSS and MLVSS vs sampling days for reactors $\mathrm{A}$ and $\mathrm{B}$. The MLVSS and MLSS was observed to be unstable during the acclimatization period and stabilized to approximately to $2100 \mathrm{mg} / \mathrm{L}$ for both 


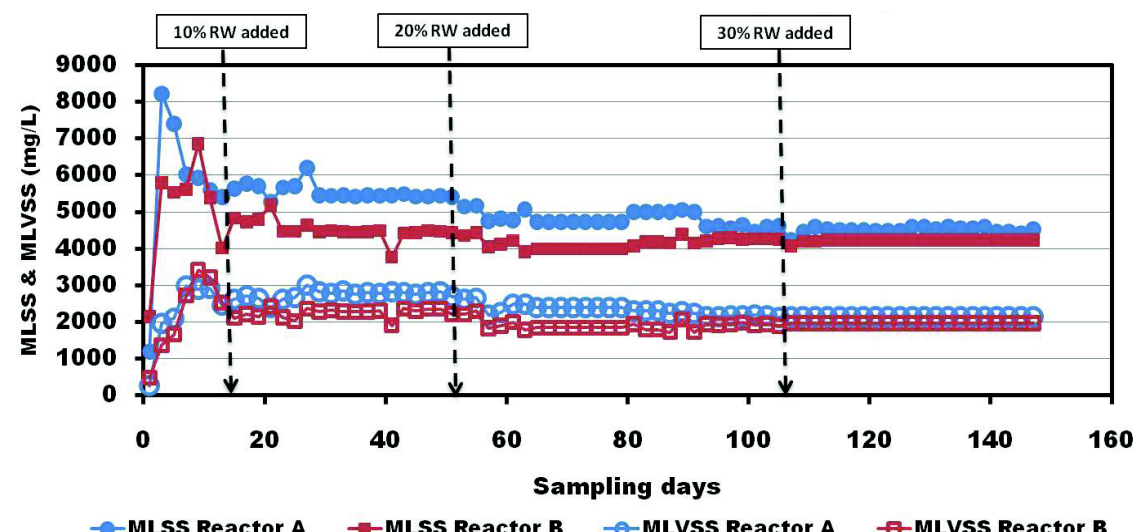

Figure 5: $\quad$ MLSS and MLVSS vs. sampling days.

reactors. It can be observed that the MLSS and MLVSS for reactor A is relatively higher than reactor $\mathrm{B}$. When the organic load of the refinery wastewater was increased to $10 \%\left(1.3 \times 10^{-7} \mathrm{~kg} \mathrm{COD} / \mathrm{m}^{3} . \mathrm{d}\right)$, a slightly lower MLSS $(\sim 4500 \mathrm{mg} / \mathrm{L})$ was observed in reactor B compared to reactor A $(\sim 5500$ $\mathrm{mg} / \mathrm{L})$ throughout this loading period. Much lower MLVSS $(\sim 2300 \mathrm{mg} / \mathrm{L})$ was observed in reactor B compared to reactor A $(\sim 2900 \mathrm{mg} / \mathrm{L})$. Some toxic impact on the biomass may be the cause of the drop in the concentrations. When the refinery loading was increased to $20 \%$ a further drop in MLSS $(\sim 4000 \mathrm{mg} / \mathrm{L})$ and MLVSS $(\sim 1800 \mathrm{mg} / \mathrm{L})$ was observed in reactor B. However, when the refinery wastewater loading was increased to $30 \%$, it was observed that the MLSS and MLVSS, for reactor B stabilized approximately at $4200 \mathrm{mg} / \mathrm{L}$ and $1900 \mathrm{mg} / \mathrm{L}$, respectively.

\subsection{Effects of $\mathrm{F} / \mathrm{M}$ ratio}

Fig. 6 shows F/M ratio vs sampling days throughout the study period. It can be observed that the $\mathrm{F} / \mathrm{M}$ ratio for both reactors was unsteady during the acclimatization period. However, the F/M ratio for reactor A stabilized after 33 sampling days. When the loading of the refinery wastewater was increased to $10 \%$, it can be observed that the $\mathrm{F} / \mathrm{M}$ ratio in reactor $\mathrm{B}$ was unstable in the beginning. However after 49 sampling days, the F/M ratio stabilized to an average of $0.05 \mathrm{~kg} \mathrm{COD} / \mathrm{kg}$ MLVSS.d at the end of the study period. Reactor A's F/M ratio was consistently at $0.02 \mathrm{~kg}$ COD $/ \mathrm{kg}$ MLVSS.d with slight increment towards the end of the study period due to increased municipal wastewater loading. When the refinery loading in reactor B was increased to $20 \%$, the $\mathrm{F} / \mathrm{M}$ ratio was consistently averaged at $0.05 \mathrm{~kg} \mathrm{COD} / \mathrm{kg}$ MLVSS.d until the end of the loading period. However, this is still in the range of $0.04-0.1 \mathrm{~kg}$ COD/kg MLVSS.d (Metcalf \& Eddy, pp 747). When the refinery loading was increased to $30 \%$ at 105 sampling days, the $\mathrm{F} / \mathrm{M}$ ratio in reactor $\mathrm{B}$ increased to 


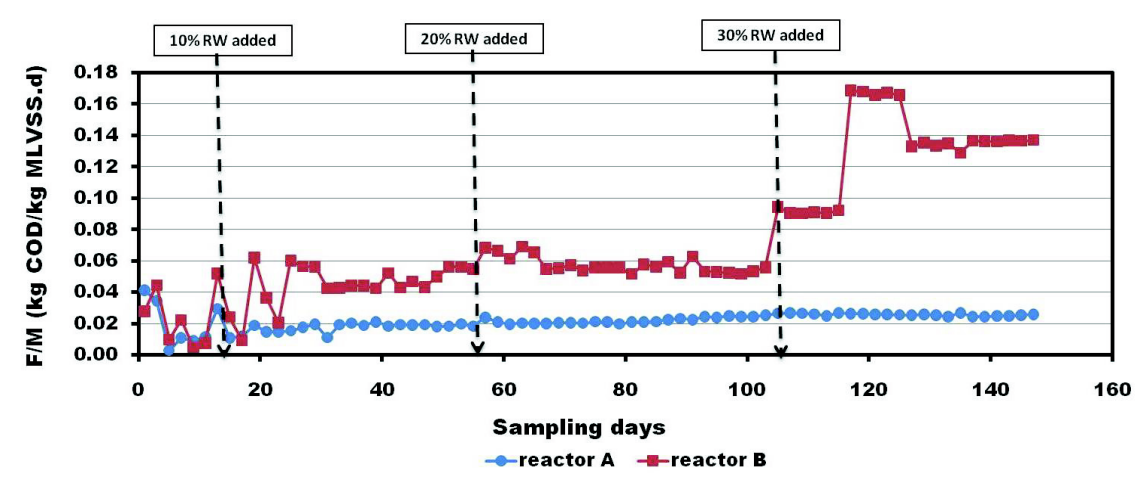

Figure 6: $\quad$ F/M ratio vs. sampling days.

$0.09 \mathrm{~kg} \mathrm{COD} / \mathrm{kg}$ MLVSS.d until 113 sampling days. However, with fresh batch samples taken from the refinery was added at $30 \%$ at 115 sampling days, the $\mathrm{F} / \mathrm{M}$ ratio increased to an average of $0.17 \mathrm{~kg} C O D / \mathrm{kg}$ MLVSS.d. It then stabilized to an average of $0.14 \mathrm{~kg}$ COD/kg MLVSS.d from 127 sampling days until the end of the loading period.

\section{Conclusion}

It can be concluded that the refinery wastewater could be co-treated with municipal wastewater up to $30 \%$ with minimal impact on effluent sCOD while still meeting the Malaysian standard effluent discharge limits. Approximately $90 \%$ removal of sCOD was achieved with $30 \%$ loading of the refinery wastewater.

\section{References}

[1] Mohamed, A., Z., Walid, E., Characterization and assessment of Al Ruwais refinery wastewater. Journal of Hazardous Materials, A136, pp. 398-405, 2006.

[2] Izanloo, H., Mesdaghinia, A., Nabizadeh, R., Naddafi, K., Nasseri, S., Mahvi, A. H., \& Nazmara, S., The Treatment of Wastewater Containing Oil with Aerated Submerged Fixed-Film Reactor. Pak. J. Bio. Sci. 10(17), pp. 2905-2909, 2007.

[3] Jou, C.-J.G., \& Huang, G.-C., A pilot study for oil refinery wastewater treatment using a fixed-film bioreactor. Advances in Env. Res, 7, pp. 463469, 2002.

[4] Tchobanoglous, G., Burton, F.L., \& Tensel, H.D., Wastewater Engineering: Treatment and Reuse, McGraw Hill Inc 4th edition: Boston, MA, 2003.

[5] Yamada, Y., \& Kawase, Y., Aerobic composing of waste activated sludge: kinetic analysis for microbial reaction and oxygen consumption. Waste Management, 26, pp. 49-61, 2006. 
[6] Chih-Ju, G., Jou, \& Guo-Chiang, H., A pilot study for oil refinery wastewater treatment using a fixed film bioreactor. Advances in Environmental Research, 7, pp. 463-469, 2003.

[7] Nemukula, A., Bacterial treatment of precious metals refinery wastewater. Honours thesis, Department of Biochemistry, Microbiology and Biotechnology, Rhodes University, Grahams town, South Africa, 2005.

[8] Yamada, Y., \& Kawase, Y., Aerobic composing of waste activated sludge: kinetic analysis for microbial reaction and oxygen consumption. Waste Management, 26, pp. 49-61, 2006.

[9] Tanya, A.B., Jeanne, M.T., \& Sheldon, J.B.D., Effect of HRT, SRT and temperature on the performance of activated sludge reactors treating bleached kraft mill effluent. Wat. Res, 30, pp. 799-810, 1996.

[10] Arceivala, S.J., Wastewater treatment and disposal, Marcel Dekker New York, pp. 892, 1981.

[11] Qasim, S.R., Wastewater treatment plants. Planning, design, and operation, Holt, Rinehart \& Winston: USA, pp. 726, 1985.

[12] Von Sperling, M., Comparison among the most frequently used systems for wastewater treatment in developing countries. Wat. Sci. Tech, 33(3), pp. 5972, 1996.

[13] Zhao-Bo, C., Dong-Xue, H., Nan-Qi, R., Yu, T., Zhen-Peng, Z., Biological COD reduction and inorganic suspended solids accumulation in a pilotscale membrane bioreactor for traditional Chinese medicine wastewater treatment. Chem. Eng. J. 155, pp. 115-122, 2009.

[14] HACH Company, Water Analysis Handbook, HACH Company, $4^{\text {th }}$ edition: Colorado, USA, 2002.

[15] HACH Company, Water Analysis Handbook, HACH Company, $4^{\text {th }}$ edition: Colorado, USA, 2002

[16] Environmental Quality Act, 1974. 